\title{
Pedagogical practices and ICT use around the world: Findings from the IEA international comparative study SITES2006
}

\author{
Editorial Introduction to this special issue
}

\author{
Tjeerd Plomp • Joke Voogt
}

Published online: 4 June 2009

(C) The Author(s) 2009. This article is published with open access at Springerlink.com

\begin{abstract}
This special issue presents a number of secondary analyses of data collected in 2006 in the Second Information Technology in Education Study (SITES 2006). This study is the last of a number of international comparative surveys on information and communication technology (ICT) in education conducted under auspices of the International Association for the Evaluation of Educational Achievement (IEA). After summarizing the aims and scope of previous studies, the aims of SITES 2006 as well as key aspects of the research design are summarized. This is followed by a brief abstract of each of the articles included in this special issue. Three articles discuss international findings of the study and also findings from three participating education systems (South Africa, Denmark, Hong Kong SAR) are presented.
\end{abstract}

Keywords ICT in education · Pedagogical practices ·

21 st century skills $\cdot$ International comparative research $\cdot$ Secondary education

\section{Introduction}

This special issue presents a number of secondary analyses of data collected in 2006 in the Second Information Technology in Education Study (SITES 2006) that was conducted under auspices of the International Association for the Evaluation of Educational Achievement (IEA).

The IEA has as its mission to conduct international comparative surveys of educational achievement in areas such as mathematics and science (the so-called

T. Plomp $(\bowtie) \cdot$ J. Voogt

Department of Curriculum Design and Educational Innovation, Faculty of Behavioral Sciences,

University of Twente, P.O. Box 217, Enschede 7500 AE, The Netherlands

e-mail: t.plomp@gw.utwente.nl 
Table 1 The three modules of SITES (from Anderson and Plomp 2009)

\begin{tabular}{lllll}
\hline Module & $\begin{array}{l}\text { Time- } \\
\text { frame }\end{array}$ & $\begin{array}{l}\text { Number of } \\
\text { countries }\end{array}$ & Issue & Data \\
\hline 1 (SITES-M1) & $1997-1999$ & 26 & What are the main trends? & $\begin{array}{l}\text { Surveys of principals and } \\
\text { of technology coordinators }\end{array}$ \\
2 (SITES-M2) & $1999-2003$ & 28 & $\begin{array}{l}\text { What innovative teaching } \\
\text { uses are made of } \\
\text { technology, and what } \\
\text { does it take? }\end{array}$ & $\begin{array}{l}\text { In-depth case studies } \\
\text { of innovative teaching } \\
\text { in schools }\end{array}$ \\
3 (SITES2006) & $2004-2008$ & $\begin{array}{c}22 \text { education } \\
\text { systems from } \\
20 \text { countries }\end{array}$ & $\begin{array}{l}\text { What pedagogical practices } \\
\text { do teachers apply and how } \\
\text { is ICT used in these? Are } \\
\text { schools ready to support this? }\end{array}$ & $\begin{array}{l}\text { Surveys of schools } \\
\text { (principals and technology } \\
\text { coordinators) and } \\
\text { (mathematics and science) }\end{array}$ \\
& & teachers.
\end{tabular}

TIMSS-studies) and reading literacy (the so-called PIRLS-studies). But, next to these achievement studies, IEA also conducts studies in other areas such as information (and communication) technology (abbreviated as ICT or IT) in education.

The first IEA Computers in Education (CompEd) study had a focus on surveying the extent to which ICT was available in schools and what problems were experienced by schools and teachers. Data were collected in 1989 (Pelgrum and Plomp 1991, 1993) and in 1992 (Pelgrum et al. 1993).

Following the CompEd studies, the IEA decided in the late 1990s to start the Second Information Technology in Education Studies (SITES) consisting of a number of phases or modules, as summarized by Anderson and Plomp (2009) in Table 1.

SITES-Module 1 (or SITES-M1) collected data in 1998 in 26 participating countries in one or more of three school levels: primary, lower secondary, and uppersecondary. As reported in Pelgrum and Anderson (1999), this module produced findings on the extent to which ICT is used in education and whether education systems have implemented objectives, and pedagogical approaches that are considered important for education in a knowledge society. Findings of SITES-M1 showed that educational systems differed a lot in this respect, but that in a few educational systems more than half of the schools had begun to use ICT to change toward a more student-centered pedagogical approach with the aim of making students more active in and responsible for their own learning. In SITES-M1, principals were asked to give an example of 'the most satisfying experience of a learning activity in their school in which students use computer-related technology which gives them the most useful, effective and advanced learning experiences with technology'. Voogt (1999) analyzed these experiences and concluded that students' activities focused on information-processing, production or communication, in combination with word-processing, technology for searching for information and technology for facilitating communication (p.220). She concluded that many of these 'most satisfying experiences' with technology were aimed at offering active/ productive learning activities to students, in which ICT played a substantial role.

In the SITES-M2 study, conducted from 2000 to 2002, so-called 'innovative pedagogical practices supported by ICT' were examined by conducting a comparative 
case study in 28 countries of such innovative practices (Kozma 2003). These case studies provided policy analysts and practitioners with good examples of how technology can change classroom teaching and provided policymakers with guidelines on how to increase the positive impact of technology on their education systems. An important finding was that the students involved in these innovative pedagogical practices often were engaged in constructing knowledge products, including tasks of searching, organizing, and evaluating knowledge. These tasks refer to skills that are often referred to as 'lifelong learning skills' or ' $21^{\text {st }}$ century skills'. The learning activities reflected pedagogical approaches that are considered important in the information or knowledge society (Voogt and Pelgrum 2005). The findings of SITES-M2 also provided a better insight regarding the contextual factors that are critical to successful implementation and sustainability of these exemplary teaching practices using ICT.

The last study in this series is the SITES 2006 study that built on the findings of the previous two SITES modules. As a number of secondary analyses of SITES 2006 data are being reported in this special issue, the aims of this study as well as key aspects of the research design are summarized here.

\section{SITES 2006}

SITES 2006 was an international comparative study of pedagogy and ICT use in schools (Law et al. 2008). The study focused on the role of ICT in teaching and learning in mathematics and science classrooms. It examined the extent to which pedagogical practices considered to be conducive to the development of " 21 st Century Skills" were present in comparison to traditionally important ones. "21st Century Skills" were defined as the capacity to engage in lifelong learning (understood as self-directed and collaborative inquiry) and as connectedness (communication and collaboration with experts and peers inside and outside the school) - as already stated above, these skills are considered important for the knowledge society. SITES 2006 also examined how teachers and students used ICT and whether ICT use contributed differentially to learning activities geared towards the development of 21 st Century Skills. In addition, analyses were conducted to identify conditions at the system, school and teacher level associated with different pedagogical practices and different ways of ICT use in teaching and learning.

\subsection{Conceptual framework and research questions}

Findings from SITES-M1 and M2, and recent national surveys and other research outcomes were used to elaborate the conceptual framework and the research questions for the study. The study took the view that

"ICT-using pedagogical practices are part of the overall pedagogical practices of the teacher. For teachers, the reasons for and the ways of using ICT in the classroom are underpinned by their overall pedagogical vision and competence. Also, pedagogical practices are not determined solely by the characteristics of the teachers, such as their academic qualifications and ICT-competence, but also by school and system-level factors. While we expect students' learning 
Fig. 1 Overall conceptual framework for the SITES 2006 study (from Law et al. 2008)

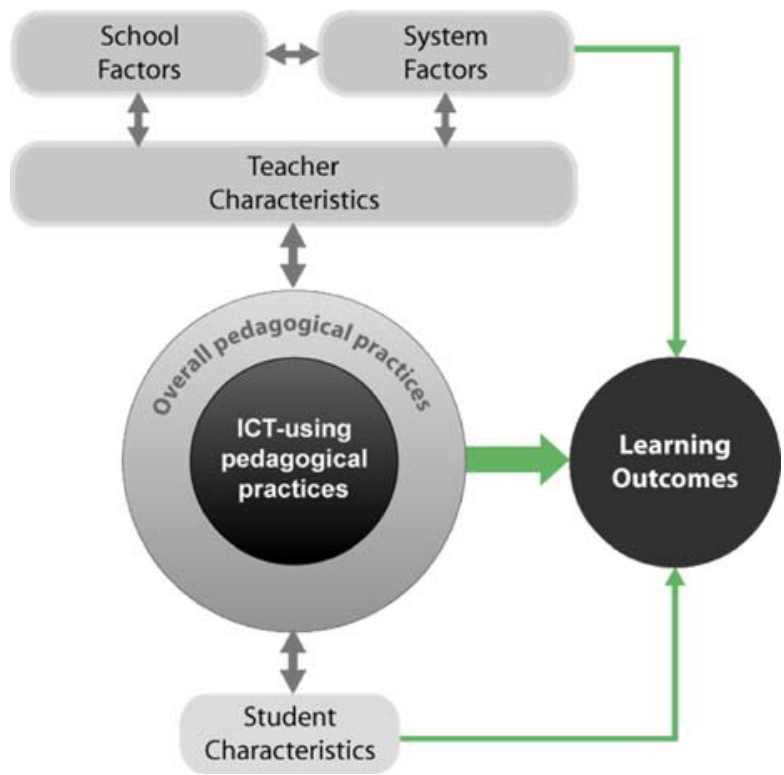

outcomes to be influenced by the pedagogical practices they experience, we need to acknowledge that the outcomes (whether perceived or actual) influence the subsequent pedagogical decisions of the teacher. This is because teacher-, school-, and system-level factors often have to change or be changed to accommodate the expected or actual impact of pedagogical practices on students." (Law et al. 2008, p.18-19).

Figure 1 presents the overall conceptual framework used for the study.

Based on this conceptualization the following research questions were phrased for the study:

1. What are the pedagogical practices adopted in schools and how is ICT used in them?

2. What ICT is used and how is it used in specific situations where ICT has been employed relatively extensively within a pedagogical practice?

3. What teacher, school, community and system factors are associated with different pedagogical approaches and ICT use, and can an explanatory model be identified?

4. What system factors are associated with different pedagogical approaches and ICT use?

\subsection{On the research design and instruments}

Indicators for each of the concepts in the framework were developed and questionnaires for school principals, school ICT-coordinators and math and science teachers were designed.

The target grade of the study was the grade that represents eight years of schooling, counting from the first year of ISCED Level 1 (OECD 1999), which is in most countries grade 8 . 
Table 2 Educational systems which participated in SITES 2006

\begin{tabular}{|c|c|c|}
\hline Canada, Alberta Province ${ }^{\mathrm{a}, \mathrm{b}}$ & $\sqrt{ }$ Hong Kong $\mathrm{SAR}^{\mathrm{a}, \mathrm{b}}$ & Russia Moscow Region \\
\hline$\sqrt{ }$ Canada, Ontario Province $^{a}$ & ${\sqrt{\text { Israel }^{\mathrm{a}}}}^{\mathrm{a}}$ & $\sqrt{ }$ Singapore $^{\mathrm{a}, \mathrm{b}}$ \\
\hline$\sqrt{ }$ Chile $^{\mathrm{b}}$ & $\sqrt{I t a l y}^{\mathrm{a}, \mathrm{b}}$ & $\sqrt{ }$ Slovak Republic ${ }^{\mathrm{a}, \mathrm{b}}$ \\
\hline$\sqrt{ }$ Chinese Taipei $^{\mathrm{a}, \mathrm{b}}$ & $\sqrt{J_{a p a n}}{ }^{\mathrm{a}, \mathrm{b}}$ & $\sqrt{ }$ Slovenia $^{\mathrm{a}, \mathrm{b}}$ \\
\hline Denmark $^{\mathrm{a}, \mathrm{b}}$ & Lithuania $^{\mathrm{a}, \mathrm{b}}$ & $\sqrt{ }$ Spain $(\text { Catalonia })^{\mathrm{b}}$ \\
\hline Estonia & Norway ${ }^{\mathrm{a}, \mathrm{b}}$ & South Africa ${ }^{\mathrm{a}, \mathrm{b}}$ \\
\hline$\sqrt{\text { Finland }^{\mathrm{a}, \mathrm{b}}}$ & Russian Federation ${ }^{\mathrm{a}, \mathrm{b}}$ & Thailand $d^{\mathrm{a}, \mathrm{b}}$ \\
\hline France $^{\mathrm{a}, \mathrm{b}}$ & & \\
\hline
\end{tabular}

Systems marked with ${ }^{a}$ participated also in SITES-M1 and those with ${ }^{\mathrm{b}}$ in SITES-M2. Systems marked with $\sqrt{ }$ met the criterion that the school participation rate is $\geq 70 \%$, necessary for inclusion in the international data analyses

Schools enrolling the target grade and math and science teachers in those grades from 22 educational systems participated in SITES2006. An overview of the educational systems participating in the study is presented in Table 2. Per educational system a representative sample of 400 schools enrolling the target grade (resulting in a total sample size of 8,700 schools) and four teachers per school (two math and two science teachers) participated in the study - see Carstens and Pelgrum (2009) for details.

The principal questionnaire contained 34 questions, among which 222 items were included to address the policy-related and school-contextual issues (Law et al. 2008). The contents of the school questionnaire are related to: pedagogical practices in schools (2 questions), pedagogy and ICT (9), staff development for teachers and the school leadership (2), pedagogical support for persons using ICT (2), obstacles in using ICT (1), organization of learning (2), school characteristics (7), and personal background information (9).

The technical questionnaire, which was designed to collect data from school technology coordinators, contained 19 questions addressing 115 items, focusing on exploring the ICT-related issues like ICT in school (3 questions), resource materials (1), hardware (6), staff development (2), support facilities for ICT (4), obstacles (1), and personal background information (2).

The teacher questionnaire contained 41 questions, all of which aims at: (i) identifying the pedagogical practices adopted in schools and how ICT is used in them, and (ii) exploring the teacher, school, community, and system factors associated with different pedagogical approaches and ICT-use (Law et al. 2008). To address the above-mentioned objectives, the 41 questions were further broken down as follows: information about the target class (7 questions), curriculum goals (1), teacher practice (7), student practice (1), learning resources and tools (1), impact of ICT use (3), the participating teachers and his/her school (16), and specific pedagogical practices in which ICT is used (5).

Data collection for SITES 2006 took place in 2005 in southern hemisphere countries and in 2006 in northern hemisphere countries. Eighteen of twenty-two educational systems participating in the study collected data on-line. Further details of the SITES 2006 research design are given in Carstens and Pelgrum (2009). 


\section{This special issue}

In this special issue, a secondary analysis of some main international findings of the study are presented and discussed. To illustrate how participating countries may utilize this study to address questions of national relevance, also findings from three countries are presented: from a developing country (South Africa), a European country (Denmark) and an Asian educational system (Hong Kong SAR).

Pelgrum and Voogt (both from the international coordinating centre of the SITES 2006) analyzed 'School and teacher factors associated with frequency of ICT use by mathematics teachers: country comparisons'. A main observation from the SITES 2006 study is that education systems differed substantially in terms of the extent to which ICT was used frequently by mathematics and science teachers (Voogt 2008). The authors thought it important, e.g. for policy makers and researchers, to acquire a better understanding of why these differences exist. In order to throw more light on this issue, in this paper school and teacher factors will be compared between education systems with relatively high versus low use of ICT in mathematics.

Law (also involved in the international coordination of the SITES 2006 study) analyzed the Mathematics and science teachers' pedagogical orientations and the use of ICT in teaching. The pedagogical orientation of the teacher is an important concept underlying the design of the SITES 2006 study, which can be broadly conceptualized as traditionally important or $21^{\text {st }}$ century oriented. The latter can be further differentiated into lifelong learning and connectedness oriented. She analyzes whether there is evidence that $21^{\text {st }}$ century pedagogy as identified in the literature and in innovative practices can be found more generally in random samples of teachers in participating countries.

Voogt addresses the question How different are ICT-supported pedagogical practices from extensive and non-extensive ICT-using science teachers? As part of SITES 2006 extensive ICT-using science teachers nominated their most satisfying pedagogical practice. Perceived student outcomes and teaching practices have been analyzed. In addition, the regular pedagogical practices of these science teachers were compared with the regular pedagogical practices of non-extensive ICT-using science teachers. The results show that although traditionally important practices within the context of ICT are still dominant in science education, changes in the equilibrium between traditionally important and innovative practice orientations are taking place across educational systems.

Howie and Blignaut (national research coordinators of SITES 2006 for South Africa) analyzed their national data from the perspective of South Africa's readiness to integrate ICT into mathematics and science pedagogy in secondary schools. They conclude that in fewer than $20 \%$ of the schools ICT is integrated in math and science classes. Also that essential conditions for integrating ICT are not yet in place in the majority of schools in South Africa and that where the hardware and software is in place, significant attention is required regarding the location of ICT, provision of staffing and the acquisition of skills and pedagogy.

Bryderup and Larsen (national research coordinators of SITES 2006 for Denmark) address an interesting phenomenon in their paper, viz ICT-use, educational policy and changes in pedagogical paradigms in compulsory education 
in Denmark: from a lifelong learning paradigm to a traditional paradigm. For years, increased use of ICT in education and training has been part of the Danish education policy, but at the same time, the pedagogical paradigm among school leaders and teachers seems to be changing from a lifelong learning paradigm (focussed on student-centred, active, and autonomous learning) to a more traditional paradigm (focussed on curriculum-centred teaching and instructions). They describe this development in relation to the way ICT is used as well as look for possible explanations of the development.

Finally, Yuen (national research coordinator of SITES 2006 for Hong Kong SAR) and Law analyzed School leadership and teachers' pedagogical orientations in Hong Kong in a comparative perspective. They explored the school leadership factors that may affect teachers' pedagogical orientations and identified eight leadership constructs covering areas such as learning goals, priority for resource allocation, types of assessment, and priority of competencies for school leadership to acquire. Their findings indicate a gap between principals' and teachers' perceptions on pedagogy and ICT use in Hong Kong.

Note The international database used for the secondary analyses can be found in the IEA's Study Data Repository at http://rms.iea-dpc.org or be available from the website of the study www. sites2006.net (which will include a clear link to the download from the home page).

Open Access This article is distributed under the terms of the Creative Commons Attribution Noncommercial License which permits any noncommercial use, distribution, and reproduction in any medium, provided the original author(s) and source are credited.

\section{References}

Anderson, R. E., \& Plomp, T. (2009). Introduction. In T. Plomp, R. E. Anderson, N. Law \& A. Quale (Eds.), Cross-national information and communication technology policies and practices in education (2nd ed., pp. 3-17). Charlotte, NC: Information Age Publishing.

Carstens, R., \& Pelgrum, W.J. (Eds.).(2009). Second Information Technology in Education study Technical Report. Amsterdam: the International Association for the Evaluation of Educational Achievement (IEA).

Kozma, R.B. (Ed.).(2003). Technology, innovation and educational change: a global perspective. Eugene, OR: International Society for Technology in Education (ISTE) and the IEA.

Law, N., Pelgrum, W.J., Monseur, C., Brese, F., Carstens, R., Voogt, J., Plomp, T., \& Anderson, R.E. (2008). Study design and methology. In. N. Law, W. J. Pelgrum and T. Plomp (Eds), Pedagogy and ICT use in schools around the world: findings from the IEA SITES 2006 study (pp. 16-37). Hong Kong: Comparative Education Research Centre, and New York, NY: Springer.

Law, N., Pelgrum, W.J., \& Plomp, T. (Eds.). (2008). Pedagogy and ICT use in schools around the world: findings from the IEA SITES 2006 study (pp. 16-37). Hong Kong: Comparative Education Research Centre, and New York, NY: Springer.

OECD, Organization for Economic Co-operation and Development.(1999). Classifying educational programmes: Manual for ISCED-97 implementation in OECD countries. Paris: author.

Pelgrum, W. J., \& Plomp, Tj. (1991). The use of computers in education worldwide: results from the IEA 'Computers in Education' survey in 19 education systems. Oxford: Pergamon.

Pelgrum, W. J., \& Plomp, Tj (Eds). (1993). Computers in Education: Implementation of an Innovation in 20 Countries. Oxford: Pergamon. 
Pelgrum, W. J., Janssen Reinen, I. A. M., \& Plomp, Tj (Eds). (1993). Schools, Teachers, Students and Computers: A Cross-National Perspective. The Hague: International Association for the Evaluation of Education Achievement.

Pelgrum, W., \& Anderson, R.E.(1999). ICT and the emerging paradigm for life-long learning: an IEA educational assessment of infrastructure, goals and practices in twenty-six countries. Amsterdam: the International Association for the Evaluation of Educational Achievement (IEA).

Voogt, J., \& Pelgrum, H. (2005). ICT and curriculum change. Human Technology; an Interdisciplinary Journal on Humans in ICT Environments, 1(2), 157-175. 